\title{
The Development of Momen of Inertia Props Based On Arduino Uno for Second Year of Senior High School Student
}

\author{
Sukindar*, Ika Kartika, Nur Untoro \\ Physics Education Department, Faculty of Science \& Technology, Universitas Islam Negeri Sunan Kalijaga, \\ J1. Marsda Adisucipto Yogyakarta 55281, Indonesia \\ *Email: sukindarkoti@gmail.com
}

\begin{abstract}
Sukindar, Kartika I, Untoro N. 2017. The Development of Momen of Inertia Props Based On Arduino Uno for Second Year of Senior High School Student. Proc Internat Conf Sci Engin 1: 229-233. Momen of inertia concept is difficult subject to teach. Many teachers still teach momen of inertia concept by using lecture method. On the orther hands, students need a momen of inertia props. It encourages researcher to 1) develop momen of inertia props based on Arduino UNO 2) measure the momen of inertia props based on Arduino UNO quality 3) study the students responses and Arduino UNO-based momen of inertia props enforceability. This research is Research and Development by Borg and Gall model that consists of seven steps, namely 1) Research and information collecting 2) Planning 3) Develop preliminary form of product 4) Preliminary field testing 5) Main product revision 6) Main field testing 7) Operational product revision. This research is using questionnaires and observation techniques in data collection process with instruments such as assessment sheets, response sheets, and observation sheet. The data were analyzed by finding the average score and compared with classification table. The research results is 1) researcher successfully developed moment of inertia props based on Arduino UNO with Student Worksheet and Teachers Guide 2) Quality of Arduino UNO-based moment of inertia props were set into Very Good category by material experts assessment, media experts assessment, and teachers assessment with average score of 3.38; 3,69; and 3.58 3) student response of the Arduino-based momen of inertia props is set into Agree category with average score of 0.97 and enforceability shows that the props can be used in momen of inertia concept learning in second year grade of Senior High School.
\end{abstract}

Keywords: Props, Moment of Inertia, Arduino UNO, Student Worksheets

\section{INTRODUCTION}

Science development isn't just about facts, but scientific method, value, and attitude (Indonesian Education Ministry 2007). Science should be studied like the development. It should be teached based on the nature of science. In this case, science study requires medias that can be used based on the nature of science.

Based on observation at MAN I Karanganom, moment of inertia is one of difficult concept of science. The average value of the exam result under the graduation criteria, and the 90 percents students who have completed the questionnaire show that moment of inertia is difficult. On the other hands, the moment of inertia concept is difficult subject to teach(Zulirfan et al. 2011).

Three teacher who have completed the interview show that many teacher still teach moment of inertia by using lecture method. This method doesn't match with nature of science and science development. Moment of inertia is an abstract concept. It requires an medias that can make concept looks like real.

The moment of inertia props is one of medias that can be the best solution. It could be used to proof the moment of inertia concept. This media can improve the student concept understanding. It can enrich the teacher learning methods, makes fun concept learning.

In fact, moment of inertia props have been developed by some peoples. But, moment of inertia props that have been developed still need an improvement. Some props couldn't show that the moment of inertia is affected by radius and mass of objects. The other props have no high accuracy measurements.

Using radius and mass of objects variation in the props could be one of improvements. The moment of inertia props can show that the radius and mass of objects affect the moment of inertia by using this variation. Using radius of object variation can explain that moment of inertia in an object is directly proportional to radius of the object. Using mass of objects variation can explain that moment of inertia is directly proportional to square of the mass.

Automatic stopwatch can be an alternative measurements enhancement. The moment of inertia props can have high accuracy measurement by adding automatic stopwatch. This improvement will reduce the response time that results between viewing process and pressing the stopwatch button.

Automatic stopwatch can be developed by using Arduino UNO board that was integrated with photodiode sensors. This board has high clock frequency that can be used to measure time and the sensor can reduce delay time that caused by user response. Arduino UNO board and photodiode sensors are the perfect combination in automatic stopwatch development.

So, all of this facts encourage researcher to develop momen of inertia props based on Arduino UNOphotodiodes integration. The props would be developed by using radius and mass of objects variation. The props also comes with students worksheets and teacher guides. 


\section{MATERIALS AND METHODS}

\section{Procedures}

This research uses Research and Development type. Educational R\&D is an industry-based development model in which the findings of research are used to design new products and procedures, which then are systematically field-tested, evaluated, and refined until they meet specified criteria of effectiveness, quality, or similiar standard (Borg and Gall 2003).

\section{Research and information collecting}

Research and information collecting are preliminary study that aimed at gathering information, identifying, and summarizing issues. Reseacher reviews the relevant literature in this step. Reseacher also makes observation by using interview and distributing questionnaires method.

\section{Planning}

Planning procedure contains research planning activity, formulation of goals, and determination of research design. The procedure is implemented based on research and information collecting procedure. The procedure also includes designing product and designing validation instruments.

\section{Develop preliminary form of product}

Develop preliminary form of product procedure contains collecting product material, developing preliminary product, and developing evaluation instuments. The procedure also cotains product and instument running test.

\section{Preliminary field testing}

Preliminary field testing procedure contains product test that aimed to get decent design in substantion and methodology. In this test, the product is tested by several experts by using evaluation instruments. The product is also tested on small scale students.

\section{Main product revision}

Main product revision procedure is product revision based on preliminary field testing results. After analyzing the test results, preliminary product would be improved based on the result.

\section{Main field testing}

Main field testing is a quantitative data test that aimed to determine the suitability of the product. This procedure contains feasibility test and effectiveness test. In the test, the product is tested on large scale students by using an instrument. Researcher also use observation method to determine the implementation of the product.

\section{Operational product revision}

Operational product revision is product revision based on main field testing results. In this step, reseacher improves quality of the product based on main field testing feedback. This procedure aims to produce a usable product.

\section{Data analysis}

This research is using questionnaires and observation techniques in data collection process with instruments such as assessment sheets, response sheets, and observation sheet. The datas were analyzed by finding the average score and compared with classification table (Eko Putro Widoyoko 2012). (Equation 1; Equation 2)

Equation 1. Average Equation.

$$
\bar{x}=\frac{\sum x}{N n}
$$

Equation 2. Classification Equestion.

$$
\begin{aligned}
\text { Interval }(i) & =\frac{\text { highest score }- \text { lowest score }}{\text { sum of interval }} \\
& =\frac{4-1}{4}=0,75
\end{aligned}
$$

\section{RESULTS AND DISCUSSION}

The research result is an moment of inertia props based on Arduino UNO-photodiode integration, included Student Worksheet and Teachers Guide. The product can be used by teacher and student. This product can be used to learn moment of inertia in the classroom, and also can be used to pratice in the laboratory.

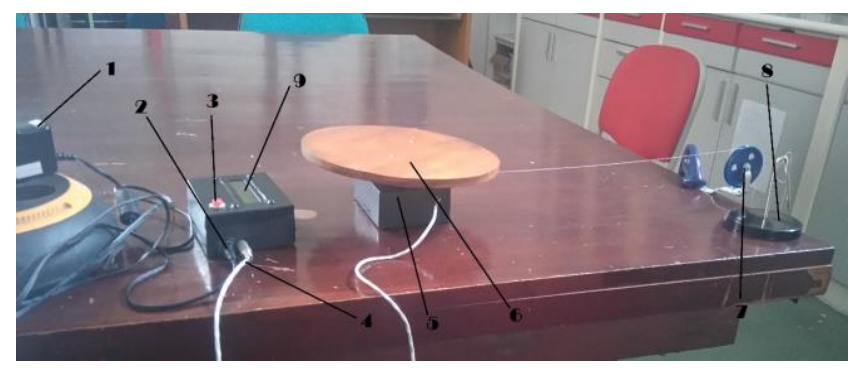

Figure 1. The moment of inerrtia props.

\section{The Product}

The moment of inertia props contains four main parts, include Sensors, Electronics, Mechanics, and Equipment. The Sensors uses two main components, namely photodiode and infrared-LED. Photodiodes are used as reciever of light, and infrared-LED is used as infrared transmitter. The Electronics uses Arduino UNO board with LCD $16 \times 2$ screen. This part also contains 5 volt DC power supply. All the Electroics components are installed into a box. The Mechanics contains disc variations, ropes, and loads. The Mechanics uses Atwood machines principle to make rotating disc. Atwood machines is a mechanical system that connects two mass by using a rope passing through a pulley (Andrew Duffy and Ali Loewy 2000). The Equipment consists two instruments, namely Student Worksheet and Teachers Guides. The student worksheet contains steps of data retrieval, observation table, and data analysis equations. The teacher guides contains product 
guides, data collection guides, and the moment of inertia concepts. (Figure 2)
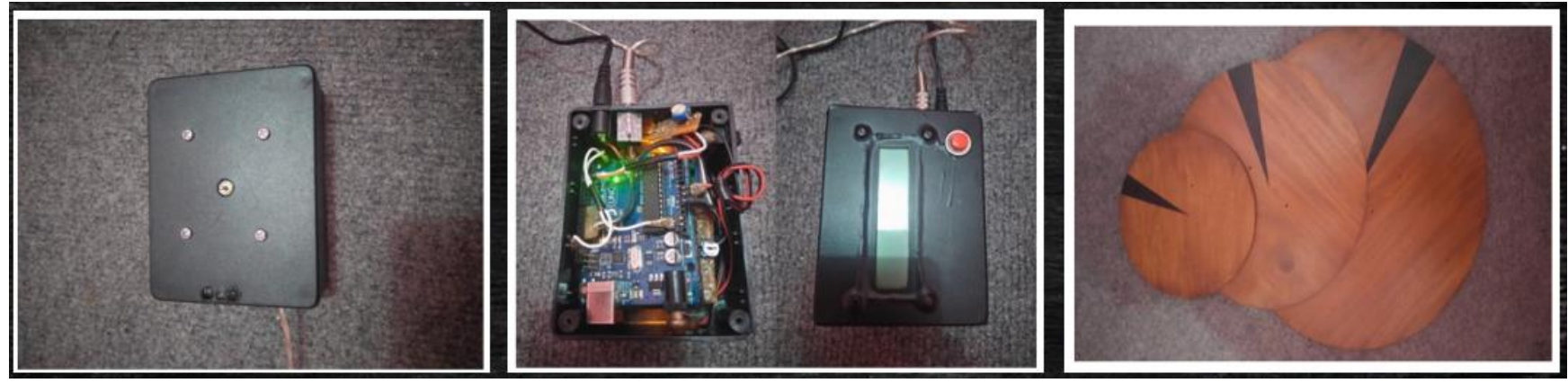

Figure 2. Sensors, Electronics, and Mechanics Parts.

\section{The Quality of Product}

The results of product assessments shows the product quality. Based on the results of product assessments, the moment of inertia props has Very Good quality criteria. This is indicated by an average value above 3.26 in the results of product assessments. The product assessment are made by media experts, material experts, and teacher.
The material experts gives an average score 3.38 . This indicates that the moment of inertia props has a Very Good quality criteria in material assessment. (Table 1)

Table 1. The Material Assessment Results.

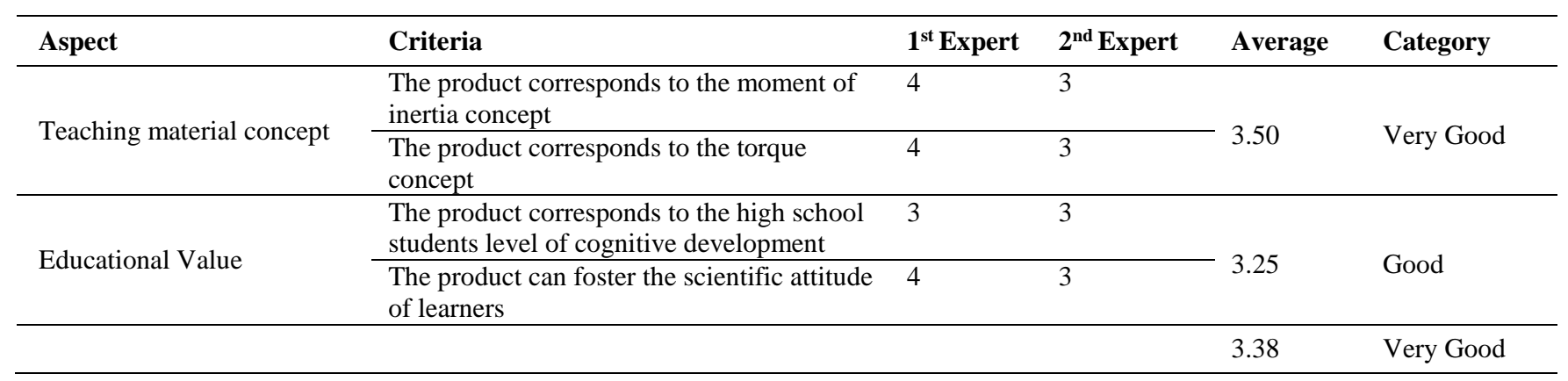

The media expert's gives an average score 3.69. This indicates that the moment of inertia props has a Very Good quality criteria in media assessment. (Table 2 )

Table 2. The Material Assessment Results.

\begin{tabular}{|c|c|c|c|c|c|}
\hline Aspect & Criteria & 1st Expert & 2nd Expert & Average & \\
\hline \multirow[t]{3}{*}{ Accuracy } & Location of infrared sensor installation & 4 & 4 & \multirow{3}{*}{3.83} & \multirow{3}{*}{ Very Good } \\
\hline & Resilience of the infrared sensor components & 4 & 4 & & \\
\hline & Accurate measuring accuracy & 4 & 3 & & \\
\hline \multirow[t]{2}{*}{ Efficiency } & Easy to assemble & 4 & 3 & \multirow{2}{*}{3.75} & \multirow{2}{*}{ Very Good } \\
\hline & Easy to use & 4 & 4 & & \\
\hline \multirow[t]{2}{*}{ Endurance } & Weatherproof & 3 & 3 & \multirow{2}{*}{3.25} & \multirow{2}{*}{ Good } \\
\hline & Easy to maintain & 3 & 4 & & \\
\hline \multirow[t]{2}{*}{ Safety } & Safety to use & 4 & 4 & 4.00 & Very Good \\
\hline & & & & 3.69 & Very Good \\
\hline
\end{tabular}

The teachers gives an average score 3.58. This indicates that the moment of inertia props has a Very Good quality criteria in teachers assessment. (Table 3 ) 
Table 3. The Teacher Assessment Results.

\begin{tabular}{|c|c|c|c|c|c|}
\hline Aspect & Criteria & 1st Expert & 2nd Expert & Average & \\
\hline \multirow[t]{2}{*}{ Teaching material concept } & $\begin{array}{l}\text { The product corresponds to the moment of } \\
\text { inertia concept }\end{array}$ & 4 & 4 & \multirow[b]{2}{*}{4.00} & \multirow[b]{2}{*}{ Very Good } \\
\hline & $\begin{array}{l}\text { The product corresponds to the torque } \\
\text { concept }\end{array}$ & 4 & 4 & & \\
\hline \multirow[t]{2}{*}{ Educational Value } & $\begin{array}{l}\text { The product corresponds to the high } \\
\text { school students level of cognitive } \\
\text { development }\end{array}$ & 3 & 4 & \multirow[t]{2}{*}{3.25} & \multirow[t]{2}{*}{ Good } \\
\hline & $\begin{array}{l}\text { The product can foster the scientific } \\
\text { attitude of learners }\end{array}$ & 3 & 3 & & \\
\hline \multirow[t]{3}{*}{ Accuracy } & Location of infrared sensor installation & 4 & 4 & \multirow{3}{*}{3.50} & \multirow{3}{*}{ Very Good } \\
\hline & $\begin{array}{l}\text { Resilience of the infrared sensor } \\
\text { components }\end{array}$ & 3 & 4 & & \\
\hline & Accurate measuring accuracy & 3 & 3 & & \\
\hline \multirow[t]{3}{*}{ Efficiency } & Easy to assemble & 4 & 4 & \multirow{3}{*}{3.67} & \multirow{3}{*}{ Very Good } \\
\hline & Easy to use & 3 & 4 & & \\
\hline & Time Allocation & 4 & 3 & & \\
\hline \multirow[t]{2}{*}{ Endurance } & Weatherproof & 4 & 3 & \multirow{2}{*}{3.25} & \multirow{2}{*}{ Good } \\
\hline & Easy to maintain & 3 & 3 & & \\
\hline \multirow[t]{2}{*}{ Safety } & Safety to use & 4 & 4 & 4.00 & Very Good \\
\hline & & & & 3.58 & Very Good \\
\hline
\end{tabular}

The Student Response and Enforceability

The student response sets the momen of inertia props into Agree category. The average value of the student response is 0.97 . (Table 4)

Table 4. The Student Responses Results.

\begin{tabular}{lll}
\hline Aspect & $\begin{array}{l}\text { Total Score / } \\
\text { aspect }\end{array}$ & Average \\
\hline Teaching material concept & 50 & 1.00 \\
Efficiency & 37 & 0.92 \\
Safety & 20 & 1.00 \\
\cline { 2 - 2 } & & 0.97 \\
\hline
\end{tabular}

The product Enforceability shows that the props can be used in momen of inertia concept learning in second year grade of Senior High School. Based on observation, all of observation aspect shows high enforceability. The observation aspect are learning objectives, completeness and efficiency of tools, response of learners.

\section{Discussion}

The main purpose of the props development is to show students that the moment of inertia concept is related to the object rotation. This can be proven by using rotating disc in momen of inertia props system. In addition, the moment of inerrtia props uses three variations of disc to show that the moment of inertia is influenced by mass and radius of the rotating object.

The principle of the props is same as periode and time counter. Firstly, the photodiode-infrared sensor would receive a dark-light pattern from the rotating disc.
The dark-light pattern change would cause data capture by Arduino UNO. With clock frequency $16 \mathrm{MHZ}$, Arduino UNO can process data very quickly. This causes Arduino can be used as an accurate timer (Bri_huang 2003). The data that will be processed into period and angular velocity data. After the data process is complete, LCD 16x2 screen would show the data.

The students and teachers also can use the props easily, because the props are equipped with student worksheet and teachers guides. The student worksheet would facilitate the retrieval of data. The teacher guides would esae the teaching process.

Based on product assessment, the props got Good category in two aspect, namely Educational Value and Endurance. The endurance got the category caused by disc use wood material. Wood material could not be weatherproof disc, so researcher replaces the material with acrylic. With acrylic material, the disc also can spin constantly.

In educational value, the props also get Good category. This is because the preliminary props is only used by three students. The solution of this problem is students can alternately use the props, or students were grouped. This solution can be used to make student responses better than ever.

Based on Student response, the props efficiency is not perfect. It because the three of ten students who completed the response sheets have difficulties in operating props. Same as problem at endurance aspect in product assessment, this is caused by wood disc cannot spin constantly.

In main field testing, the enforceability of the product can be seen. The product is tested by used in 
learning prosess. The product is used by teacher in classroom. Based on the observation, student responses did not get Very High criteria. This happens because some students forget about the basic material that has been taught, so the teacher must repeat the basic material that makes some students bored. But, overall aspect show that the props has Very High criteria in enforceability.

\section{CONCLUSIONS}

Based on the above description, it can be concluded that the moment of inertia props has been successfully developed to facilitate teachers and students in learning moment of inertia. The moment of inertia props also get Very Good category in product assessment and Very High in student response.

\section{ACKNOWLEDGEMENT}

We are very grateful to the parties who have helped this research, especially the experts who have provided advice and feedback on the product.

\section{REFERENCES}

Andrew Duffy \& Ali Loewy. 2000. Atwood's Machine. http://physics.bu.edu/ duffy/semester1/c5_atwood.html

Bri_Huang. 2003. Vernier Shield Hookup Guide. https://learn.sparkfun.com/tutorials/vernier-shield-hookupguide/example-2---photogate-timer

Departemen Pendidikan nasional. 2007. Naskah Akademik Kajian Kebijakan kurikulum Mata Pelajaran IPA, Jakarta.

Gall, M. D., Gall, J. P., \& Borg, W. R.. 2003. Educational Research An Introduction Five Edition, Boston.

Widoyoko, Eko Putro. 2012. Teknik Penyusunan Instrumen Penelitian, Yogyakarta.

Zulirfan, Ersa Desmelinda, \&Hendar Sudrajad. .2011. Pengembangan Perangkat percobaan Momen Inersia dan Keseimbangan Benda Tegar Sebagai Media Pembelajaran Fisika SMA. Jurnal Pendidikan Volume 2: 2086-4779 
THIS PAGE INTENTIONALLY LEFT BLANK 